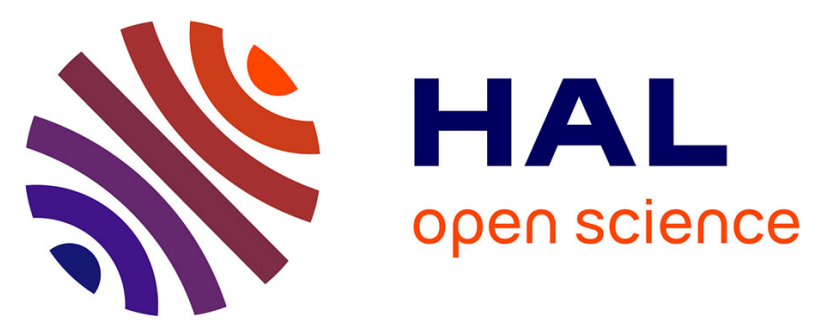

\title{
A combination therapy with fludarabine, mitoxantrone and rituximab induces complete immunophenotypical remission in B-cell prolymphocytic leukaemia
}

Adrian Tempescul, Johanna Feuerbach, Jean-Christophe Ianotto, Florence Dalbies, Veronique Marion, Marie-Josée Bris, Marc Braekeleer, Christian C. Berthou

\section{To cite this version:}

Adrian Tempescul, Johanna Feuerbach, Jean-Christophe Ianotto, Florence Dalbies, Veronique Marion, et al.. A combination therapy with fludarabine, mitoxantrone and rituximab induces complete immunophenotypical remission in B-cell prolymphocytic leukaemia. Annals of Hematology, 2008, 88 (1), pp.85-88. 10.1007/s00277-008-0541-5 . hal-00486516

\section{HAL Id: hal-00486516 https://hal.science/hal-00486516}

Submitted on 26 May 2010

HAL is a multi-disciplinary open access archive for the deposit and dissemination of scientific research documents, whether they are published or not. The documents may come from teaching and research institutions in France or abroad, or from public or private research centers.
L'archive ouverte pluridisciplinaire HAL, est destinée au dépôt et à la diffusion de documents scientifiques de niveau recherche, publiés ou non, émanant des établissements d'enseignement et de recherche français ou étrangers, des laboratoires publics ou privés. 


\title{
A combination therapy with fludarabine, mitoxantrone and rituximab induces complete immunophenotypical remission in B-cell prolymphocytic leukaemia
}

\author{
Adrian Tempescul • Johanna Feuerbach • \\ Jean-Christophe Ianotto • Florence Dalbies • \\ Veronique Marion • Marie-Josée Le Bris • \\ Marc De Braekeleer • Christian Berthou
}

Received: 28 January 2008 / Accepted: 16 June 2008 / Published online: 25 July 2008

(C) Springer-Verlag 2008

\section{Dear Editor,}

We present here the cases of two patients with B-cell prolymphocytic leukaemia (B-PLL), both expressing a translocation $\mathrm{t}(8 ; 14)(\mathrm{q} 24 ; \mathrm{q} 32)$ with rearrangement of $\mathrm{c}$ myc gene found in FISH analysis. A treatment protocol that includes six cycles of Fludarabine and Mitoxantrone followed by four injections of Rituximab allows obtaining complete cytological and immunophenotypical remission.

B-PLL is a rare disease that accounts for less than $2 \%$ of chronic lymphatic leukaemia (CLL). The characteristics of the disease include high lymphocytosis, over 4 Gigas/L, with at least $55 \%$ cells described as prolymphocytes and splenomegaly. The prolymphocytes are medium-sized cells with prominent, round or oval nuclei and a single, central

A. Tempescul $(\bowtie) \cdot$ J. Feuerbach · J.-C. Ianotto $\cdot$ F. Dalbies $\cdot$

C. Berthou

Department of Clinical Hematology,

Institute of Cancerology and Hematology,

CHU Morvan, Avenue Foch,

29609 Brest, France

e-mail: tempescul@hotmail.com

V. Marion

Laboratory of Haematology,

CHU Morvan, Avenue Foch,

29609 Brest, France

M.-J. Le Bris • M. De Braekeleer

Laboratory of Histology, Embryology and Cytogenetics,

Faculty of Medicine and Health Sciences,

Université de Bretagne Occidentale,

22, avenue Camille Desmoulins, CS 93837,

29238 Brest, Cedex 3, France nucleolus [1]. Bone marrow aspirate shows a heavy infiltration by prolymphocytes with a variable degree of residual haematopoiesis. Immunophenotypically, there is a strong expression of the B-cell antigens CD19, CD20, $\mathrm{CD} 21, \mathrm{CD} 79 \mathrm{~b}$ and FMC7 and of surface IgM, whereas CD23 is negative and CD5 is variably expressed [1].

In cytogenetic studies, the implication of the $14 \mathrm{q} 32$ region of the chromosome 14 is found in $50 \%$ of the cases [1]. Translocation $(11 ; 14)$ is present in $25 \%$ of the cases, in particular $\mathrm{t}(11 ; 14)(\mathrm{q} 13 ; \mathrm{q} 32)$ with a rearrangement of bcl1 protein. Other partners for the IgH gene of the $14 \mathrm{q} 32$ region of chromosome 14 could be genes from the regions $11 \mathrm{q} 23$ and $13 \mathrm{q} 14$ [1]. A translocation $(8 ; 14)(\mathrm{q} 24 ; \mathrm{q} 32)$ typically exists in type 3, B-cell acute lymphoblastic leukaemia and Burkitt lymphomas. This anomaly, which also involves cmyc, was found in only a few cases [2,3].

B-PLL is not treated when asymptomatic or there are no signs of bone marrow deficiency. Treatment options are various, including combination chemotherapies with alkylating agents or purine nucleoside analogues as monotherapy. Monoclonal antibodies such as Rituximab and Alemtuzumab are also used.

A 63-year-old man was first seen in October 2006 with symptoms of asthenia and dyspnoea. A physical examination revealed a splenomegaly grade 3 and lymphadenopathy. The blood count showed a significant anaemia $(\mathrm{Hb} 5,4 \mathrm{~g} / \mathrm{dL})$, thrombocytopenia (108 Gigas/L) and a hyperleukocytosis at 247Gigas/L with 92\% abnormal circulating lymphocytes, which presented the typical morphology and phenotype of B-PLL. Genetic studies revealed a complex caryotype (Fig. 1), involving a translocation $\mathrm{t}(8 ; 14)(\mathrm{q} 24 ; \mathrm{q} 32)$ with a rearrangement of c-myc, confirmed by fluorescence in situ hybridisation analysis (Fig. 2). 
Fig. 1 Conventional cytogenetics showing the 49,XY, $+\operatorname{der}(3) \mathrm{t}$ $(3 ; 18)(\mathrm{p} 11 ; \mathrm{q} 11),+\operatorname{der}(3) \mathrm{t}(3 ; 18)$ $(\mathrm{p} 11 ; \mathrm{q} 11),+7, \mathrm{t}(8 ; 14)(\mathrm{q} 24 ; \mathrm{q} 32)$, $\operatorname{der}(9) \mathrm{t}(1 ; 9)(\mathrm{q} 22 ; \mathrm{q} 34)$ karyotype in patient 1
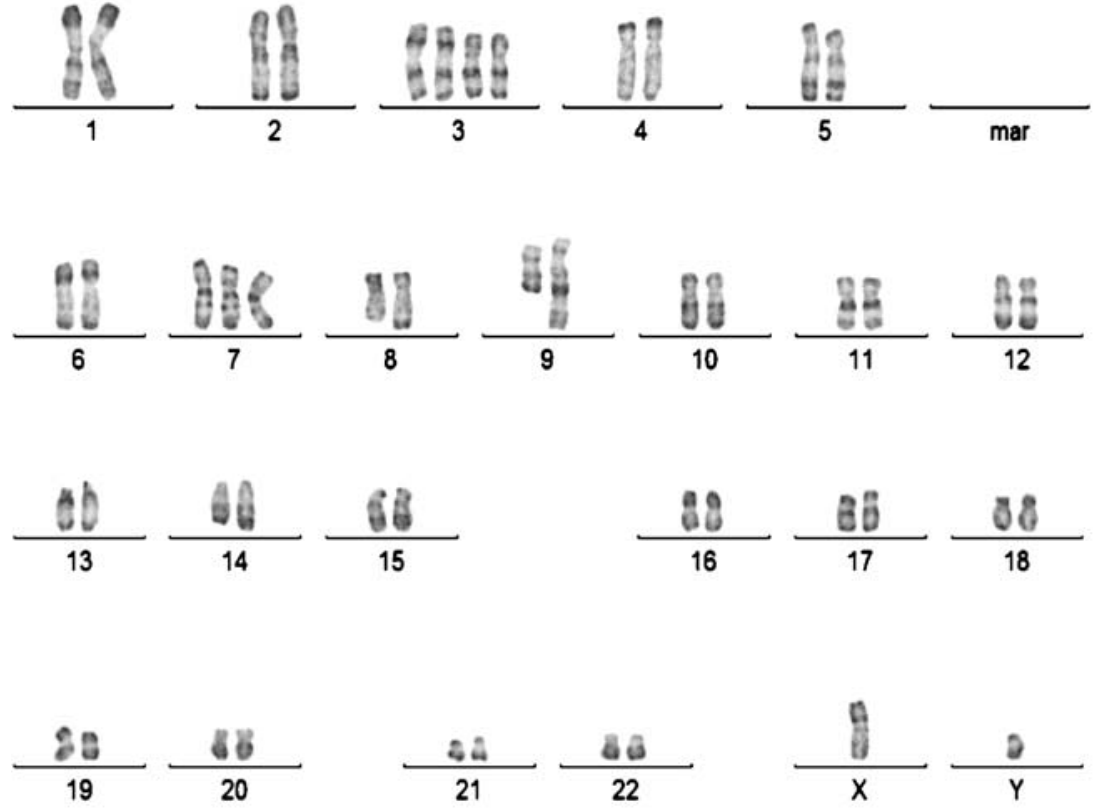

The leukaemia was resistant to initial treatment by Pentostatine and Dexamethasone association and to Burkittlymphoma standard therapy: COPADM (Methotrexate, Doxorubicine, Cyclophosphamid and Vincristin). A third-line treatment by Fludarabine (25mg/sqm D1-D5), Mitoxantrone $(12 \mathrm{~ms} / \mathrm{sqm}$ at D1) was introduced, with complete cytological and immunophenotypical remission. At the end of treatment,

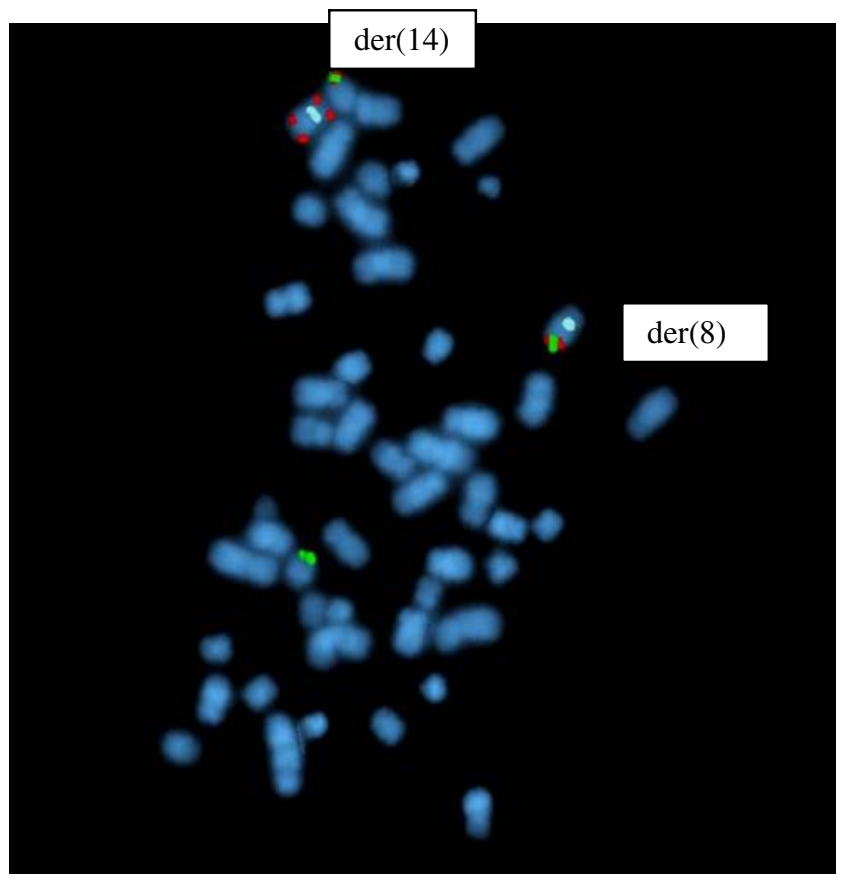

Fig. 2 FISH using LSI IGH (spectrum green)/MYC (spectrum orange), CEP8 (spectrum aqua) tri-colour, dual fusion translocation probes (Abbott, Rungis, France) showing the $\mathrm{t}(8 ; 14)(\mathrm{q} 24 ; \mathrm{q} 32)$ in patient 1 the splenomegaly was at $1 \mathrm{~cm}$ and we did not notice any lymphadenopathy. After six cycles of chemotherapy, the patient had a major lymphopenia at $0.03 \mathrm{Gigas} / \mathrm{L}$, without any circulating B-cell, and a normal bone marrow aspirate. The remission was consolidated by four weekly cycles of Rituximab $(375 \mathrm{mg} / \mathrm{sqm})$. The patient is in complete cytological and immunophenotypical remission at 6months.

We followed the case of a 70-year-old woman presenting a hyperleukocytosis (13.9Gigas/L) since 2003, with $43 \%$ abnormal circulating B lymphocytes which presented the morphology and the phenotype of B-PLL. The genetic

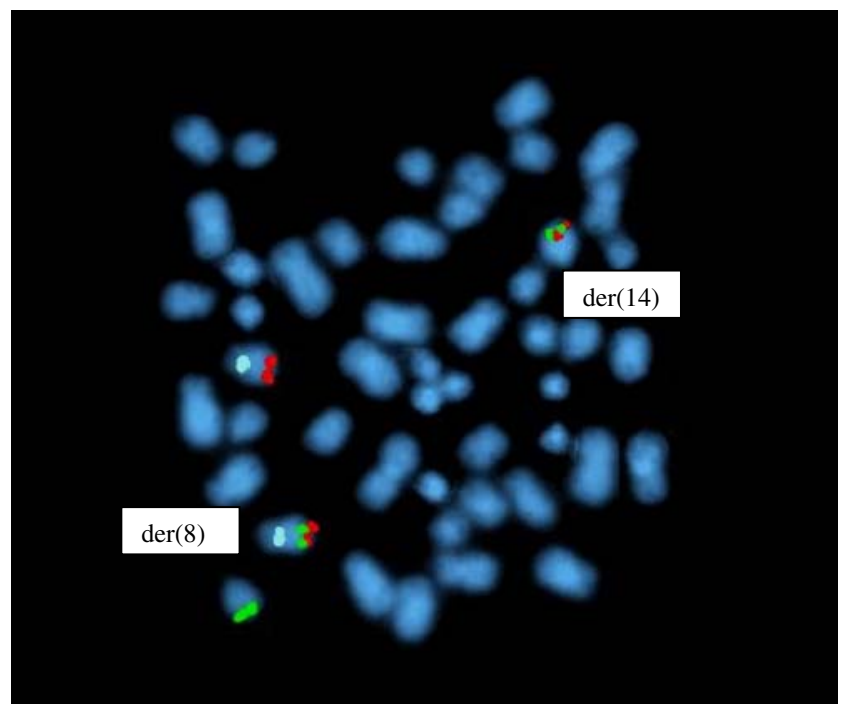

Fig. 3 FISH using LSI IGH (spectrum green)/MYC (spectrum orange), CEP8 (spectrum aqua) tri-colour, dual fusion translocation probes (Abbott) showing the $\mathrm{t}(8 ; 14)(\mathrm{q} 24 ; \mathrm{q} 32)$ in patient 2 
analysis found the presence of a complex caryotype with translocation $\mathrm{t}(8 ; 14)(\mathrm{q} 24 ; \mathrm{q} 32)$ with a rearrangement of $\mathrm{c}$ myc gene confirmed in FISH analysis (Fig. 3).

Four years after the diagnosis, we decided to treat the patient because of the presence of signs of evolution: lymphocytosis at 85 Gigas/L with $89 \%$ B prolymphocytes, signs of medullar failure - anaemia at $11 \mathrm{~g} / \mathrm{dL}$ and the presence of grade 2 splenomegaly. We used the same association: Fludarabine $(25 \mathrm{mg} / \mathrm{sqm}$ D1-D5) and Mitoxantrone $(12 \mathrm{mg} / \mathrm{sqm}$ at D1).

After three cycles of Fludarabine and Mitoxantrone, the patient achieved a complete cytological and immunophenotypical remission (CR). The grade 2 splenomegaly, noticed at the time of diagnosis, disappeared at course 3 of chemotherapy. The monoclonal antibody Rituximab was used as consolidation therapy. The patient is in complete remission at 5 months.

B-PLL is a rare disease that has a more critical prognosis than typical chronic lymphocytic leukaemia. A longer period of static disease occurs less frequently than in CLL. In this article, we described the cases of two patients with very different clinical presentations, one showing a sudden, more aggressive presentation of the disease while the other patient was asymptomatic for years. These findings correspond to an Israeli study that emphasised the heterogeneity of this disease [4].

Translocation $(8 ; 14)(\mathrm{q} 24 ; \mathrm{q} 32)$, as found in both of our cases, is frequently found in B-cell acute lymphoblastic leukaemia, Burkitt lymphomas and other non-Hodgkin lymphomas. However, some rare cases of $\mathrm{t}(8 ; 14)(\mathrm{q} 24 ; \mathrm{q} 32)$ in B-PLL are reported $[2,3]$. One could consider that B-cell PLL typically presents this translocation, associated with splenomegaly and lymphocytosis. The presence of TP53 mutations in B-PLL has a peculiar prognosis; the outcome is marked by a tendency towards high-grade transformation [4].

In a multicentric study of 41 patients, Hercher et al. found two groups of patients according to their clinical course: patients who died within the first year after the diagnosis and a second group, patients who had a prolonged survival, without any treatment in some cases. The differences between the two groups were the age of patients and the presence of anemia. They also noticed that the patients with p53 mutations had the worst prognosis [5].

There is no consensus on how to treat this entity, which presents the translocation $\mathrm{t}(8 ; 14)(\mathrm{q} 24 ; \mathrm{q} 32)$ of B-PLL. It is considered incurable and is usually not treated when asymptomatic. Combination chemotherapy with alkylating agents (COP, CHOP) allowed promising results in several studies. Nevertheless, CR was achieved in only a few cases [6-8]. In different studies, the purine nucleoside analogues Fludarabine, Cladribine or Pentostatin, used alone, allowed achieving $\mathrm{CR}$ in $0 \%$ to $11 \%$ of the cases and PR in $11 \%$ to
$60 \%[7,9]$. CR has also been reported with the monoclonal antibodies Alemtuzumab and Rituximab [10-12]. We treated our patients according to a protocol including a combination of a purine analogue: Fludarabine and an anthracendione: Mitoxantrone followed by four consolidating injections of monoclonal antibody: Rituximab. This combination therapy allowed obtaining complete cytological and immunophenotypical remission. The tolerance of the treatment was very good; the patients did not require intercourse hospitalisation.

In this article, we reported about two cases of B-PLL, with very different clinical presentations. The cytogenetic analysis revealed in both cases a rare translocation: $\mathrm{t}(8 ; 14)$ (q24;q32). In both cases, we could found, in FISH analysis, the rearrangement of the c-myc gene. The use of a combination chemotherapy including Fludarabine, Mitoxantrone and Rituximab allowed achieving cytological and immunophenotypical remission.

Even if the follow up of the patients is still short, our results encourage further investigations, suggesting that the treatment protocol associating Fludarabine, Mitoxantrone and Rituximab could be an alternative as first-line treatment of this entity.

\section{References}

1. Robak T, Robak P (2007) Current treatment options in prolymphocytic leukaemia. Med Sci Monit 13(4):RA69-RA80

2. Kuriakose P, Perveen N, Maeda K, Wiktor A, Van Dyke DL (2004) Translocations $(8 ; 14)(\mathrm{q} 24 ; \mathrm{q} 32)$ as the sole cytogenetic abnormality in B-cell prolymphocytic leukaemia. Cancer Genet Cytogenet 150(2):156-158

3. Crisostomo RH, Fernandez JA, Caceres W (2007) Complex caryotype including chromosomal translocation $(8 ; 14)(\mathrm{q} 24 ; \mathrm{q} 32)$ in one case with B-cell prolymphocutic leukaemia. Leuk Res 31 (5):699-701 doi:10.1016/j.leukres.2006.06.010

4. Nguyen-Khac F, Davi F, Receveur A, Maloum K, Morel V, Le Garff-Tavernier M et al (2005) Burkitt-type acute leukemia in a patient with B-prolymphocytic leukemia: evidence for a common origin. Cancer Genet Cytogenet 159(1):74-78 doi:10.1016/j. cancergencyto.2004.09.016

5. Hercher C, Robain M, Davi F, Garand R, Flandrin G, Valensi F et al (2001) Groupe Français d'Hématologie Cellulaire- "A multicentric study of 41 cases of B-prolymphocytic leukemia: two evolutive forms". Leuk Lymphoma 42(5):981-987 doi:10.3109/ 10428190109097717

6. Shvidel L, Shtalrid M, Bassous L, Klepfish A, Vorst E, Berrebi A (1999) B-cell prolymphocytic leukaemia: a survey of 35 patients emphasizing heterogeneity, prognostic factors and evidence for a group with an indolent course. Leuk Lymphoma 33(1-2):169-179

7. Taylor HG, Butler WM, Rhoads J, Karcher DS, Detrick-Hooks B (1982) Prolymphocytic leukemia: Treatment with combination chemotherapy to include doxorubicin. Cancer 49:1524-1529 doi:10.1002/ 1097-0142(19820415)49:8<1524::AID-CNCR2820490803>3.0. $\mathrm{CO} ; 2-\mathrm{U}$

8. Sibbald R, Catovsky D (1979) Complete remission in prolymphocytic leukaemia with the combination chemotherapy CHOP. Br J Haematol 42(3):488-490 doi:10.1111/j.1365-2141.1979.tb01159.x 
9. Montillo M, Tedeschi A, O'Brien S, Di Raimondo F, Lerner S, Ferrajoli A et al (2003) Phase II study of cladribine and cyclophosphamide in patients with chronic lymphocytic leukemia and prolymphocytic leukemia. Cancer 97:114-120 doi:10.1002/ cncr.11000

10. Mourad YA, Taher A, Chehal A, Shamseddine A (2004) Successful treatment of B-cell prolymphocytic leukemia with monoclonal anti-CD20 antibody. Ann Hematol 83(5):319-321 doi:10.1007/s00277-003-0805-z
11. Perz J, Topaly J, Fruehauf S, Hensel M, Ho AD (2002) Level of CD 20-expression and efficacy of rituximab treatment in patients with resistant or relapsing B-cell prolymphocytic leukemia and B-cell chronic lymphocytic leukemia. Leuk Lymphoma 43(1):149-151 doi:10.1080/ 10428190210178

12. Chaar BT, Petruska PJ (2007) Complete response to Alemtuzumab in a patient with B prolymphocytic leukaemia. Am J Hematol 82(5):417 doi:10.1002/ajh.20843 